\title{
INTRAOCULAR PRESSURE CHANGES AFTER UNEVENTFUL PHACOEMULSIFICATION IN EARLY POSTOPERATIVE PERIOD IN HEALTHY EYES
}

\author{
Miloš Todorović ${ }^{1}$, Tatjana Šarenac Vulović ${ }^{2,3}$, Nenad Petrovićé, \\ Dušan Todorović ${ }^{3}$ and Sunčica Srećkovićc, ${ }^{2,3}$ \\ ${ }^{1}$ Oftalmos, Paraćin, Serbia; \\ ${ }^{2}$ Ophthalmology Department, Kragujevac Clinical Centre, Kragujevac, Serbia; \\ ${ }^{3}$ Department of Ophthalmology, Faculty of Medical Sciences, University of Kragujevac, Kragujevac, Serbia
}

\begin{abstract}
SUMMARY - The aim was to determine early changes in intraocular pressure (IOP) following uneventful phacoemulsification and intraocular lens (IOL) implantation in healthy eyes. This prospective interventional case series study was conducted at Ophthalmology Department, Kragujevac Clinical Centre, Kragujevac, Serbia. The study included 123 eyes of 123 cataract patients, 66 women and 57 men, age range $50-88$ (mean 70.73 \pm 7.94 ) years having undergone phacoemulsification and in-thebag implantation of a foldable IOL. The patients were treated at Kragujevac Clinical Centre between June 2015 and May 2016. IOP was measured by Goldmann applanation tonometry preoperatively, then 4-6 hours, 18-24 hours and 7 days postoperatively by the same examiner. The mean IOP preoperatively was $15.10 \pm 2.68 \mathrm{~mm} \mathrm{Hg}$. In three patients, maximum measured IOP was $22 \mathrm{~mm} \mathrm{Hg}$. At 4-6 hours postoperatively, the mean IOP was $24.29 \pm 7.56 \mathrm{~mm} \mathrm{Hg}(\mathrm{p}<0.001)$, at $18-24$ hours it was $18.37 \pm 4.80 \mathrm{~mm} \mathrm{Hg}(\mathrm{p}<0.001)$, and 7 days after the surgery the mean IOP was $16.24 \pm 2.90 \mathrm{~mm} \mathrm{Hg}$ $(\mathrm{p}<0.05)$. The measured IOP values were statistically significant in all measured times. However, at 4-6 hours and $18-24$ hours, the mean IOP value was highly statistically significant $(p<0.001)$. Although 7 days after the surgery IOP normalized, the mean IOP value was statistically significant $(p<0.05)$. In conclusion, our research showed that even eyes with normal preoperative values and uncomplicated phacoemulsification course can show very high IOP values postoperatively, which can cause pain, blurred vision and, rarely, compromise visual function.
\end{abstract} ocular

Key words: Intraocular pressure; Phacoemulsification; Lens implantation, intraocular; Tonometry,

\section{Introduction}

Phacoemulsification has many benefits, including rapid wound healing, low postoperative complication rates, short visual recovery time, and satisfied patients. An increase in intraocular pressure (IOP) after cataract surgery is well documented ${ }^{1}$. The pathogenesis of IOP elevation is multifactorial, involving inflamma-

Correspondence to: Miloš Todorović, MD, 6.B. Brigade 45, 34000 Kragujevac, Serbia

E-mail: milostodorovic@dr.com

Received May 25, 2017, accepted January 30, 2018 tion, hemorrhage, pigment dispersion, and retained viscoelastic material, lens, or iris debris. If left untreated, uncontrolled postoperative IOP spikes can result in pain, corneal edema, glaucomatous optic nerve damage, and very rarely anterior ischemic optic neuropathy ${ }^{2}$. The pattern of IOP change after uneventful phacoemulsification shows a gradual rise in the early postoperative hours, reaches its maximum level 4 to 6 hours after surgery, and is followed by pressure normalization one day after surgery ${ }^{3}$. In this study, our aim was to determine IOP changes at 4 to 6 hours, 18 to 24 hours and 7 days following uncomplicated clear corneal phacoemulsification surgery. 


\section{Patients and Methods}

This prospective study was performed on 123 eyes of 123 consecutive patients with cataracts who underwent phacoemulsification and in-the-bag implantation of a foldable intraocular lens (IOL) between June 2015 and May 2016. All subjects gave their informed consent for participation in the study and ethical guidelines of the Declaration of Helsinki were followed during the study. Preoperatively, all patients underwent standard ophthalmic examination including the best corrected visual acuity (Snellen chart), anterior segment examination, Goldman applanation tonometry, posterior segment examination by indirect ophthalmoscopy and gonioscopy.

Patients included in the study were free from optic nerve/disc changes suggestive of glaucomatous damage and none of the patients had used glaucoma medications preoperatively. All study patients had IOP lower than $22 \mathrm{~mm} \mathrm{Hg}$ and only patients with grade 3 or 4 angle using Shaffer grading criteria were included.

Patients with previous eye trauma, pseudoexfoliation syndrome, glaucoma, prior intraocular surgery and those developing any complication during or after surgery were excluded. Goldmann applanation tonometry was performed preoperatively, and then at 4-6 hours, 18-24 hours and 7 days postoperatively by the same examiner. Clear corneal phacoemulsification and foldable IOL implantation were performed. The same surgeon performed all surgeries at a single surgical center. All procedures were done under topical anesthesia. A 2.70-mm 3-step clear corneal self-sealing incision was made in the superior cornea and the anterior chamber was filled with $1 \%$ sodium hyaluronate (Bio-Hyalur, Biotech Ophthalmics, Hertfordshire, United Kingdom). Continuous curvilinear capsulorhexis and hydrodissection of the nucleus were performed. Phacoemulsification of the nucleus was performed with the stop and chop technique, using a Millennium phacoemulsifier (Storz, Bausch \& Lomb, Rochester, NY, USA). A bimanual technique was used to remove the remaining cortex, and the bag was refilled with viscoelastic. The incision was enlarged to 3.0 $\mathrm{mm}$ to allow implantation of a foldable IOL lens (LEDAphil Hydrophilic IOL and LEDAphob Hydrophobic IOL, Hempro Ltd., Solihull Birmingham, United Kingdom) in the bag; viscoelastic was removed by irrigation-aspiration. In addition, the IOL was also gently moved back and forth to promote the release of all visible viscoelastic material from behind the lens. The anterior chamber was reformed with balanced saline solution (BSS), and the corneal wound and side ports were hydrated with BSS and left unsutured. Each patient received only cefuroxime $(1 \mathrm{mg} / 0.1 \mathrm{~mL})$ intracamerally; no miotics and anesthesia were used intracamerally at any time during the procedure. At the end of the procedure, all incisions were tested with fluorescein strips for watertight status to confirm the absence of leakage. Topical dexamethasone with tobramycin (TobraDex, Alcon, Rijksweg, Belgium) solution was instilled into the conjunctival lower fornix at the end of the operation. One day after the surgery, dexamethasone with tobramycin (TobraDex, Alcon, Rijksweg, Belgium) drops was started every 4 hours for a week, then 4 times a day for three weeks. Ofloxacin (Floxal, Dr. Gerhard Mann, Chem.-Pharm. Fabrik $\mathrm{GmbH}$, Berlin, Germany) eye drops were prescribed 4 times a day for seven days.

All statistical analyses were performed using SPSS software (version 20.0.0, SPSS, Inc., Armonk, New York, USA). Statistical significance of IOP changes was determined using one-way analysis of variance and paired samples $\mathrm{T}$ test. The level of statistical significance was set at $\mathrm{p}<0.05$.

\section{Results}

The study included 123 eyes of 123 patients, 66

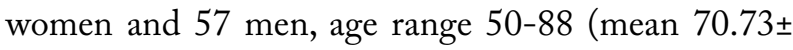
7.94) years. The mean IOP preoperatively was $15.10 \pm$ 2.68 (range 9-22) $\mathrm{mm} \mathrm{Hg}$, and maximum measured IOP in three patients was $22 \mathrm{~mm} \mathrm{Hg}$ (Fig. 1). Four to

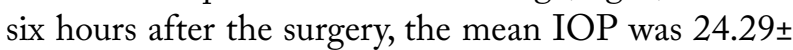
7.56 (range 8-60) $\mathrm{mm} \mathrm{Hg}(\mathrm{p}<0.001)$, and 75 patients showed IOP elevation of over $22 \mathrm{~mm} \mathrm{Hg}$. IOP rise was shown in 25 patients, with values above $30 \mathrm{~mm}$ $\mathrm{Hg}$, where six of them had values of IOP above $40 \mathrm{~mm}$ $\mathrm{Hg}$. The six patients with the IOP rise above $40 \mathrm{~mm}$ $\mathrm{Hg}$ received the same postoperative medications for IOP lowering (oral acetazolamide $250 \mathrm{mg}$ in 2 daily doses) (Fig. 2). Eighteen to twenty-four hours later, the mean IOP was $18.37 \pm 4.80$ (range $6-40$ ) $\mathrm{mm} \mathrm{Hg}$ $(\mathrm{p}<0.001)$, and 27 patients had IOP values higher than $22 \mathrm{~mm} \mathrm{Hg}$ (Fig. 3). Seven days after the surgery, the mean IOP was $16.24 \pm 2.90$ (range $8-24$ ) $\mathrm{mm} \mathrm{Hg}$ 


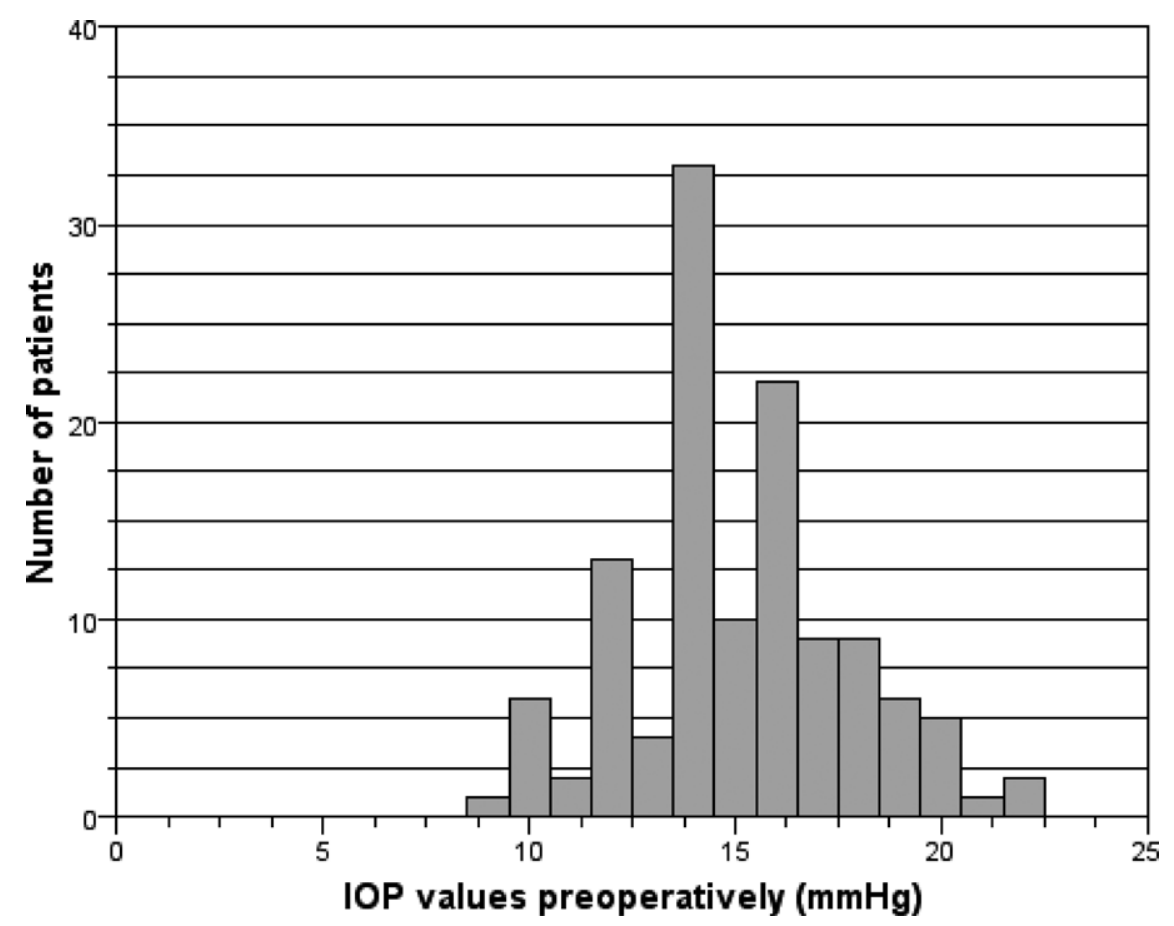

Fig. 1. Values of intraocular pressure (IOP) preoperatively.

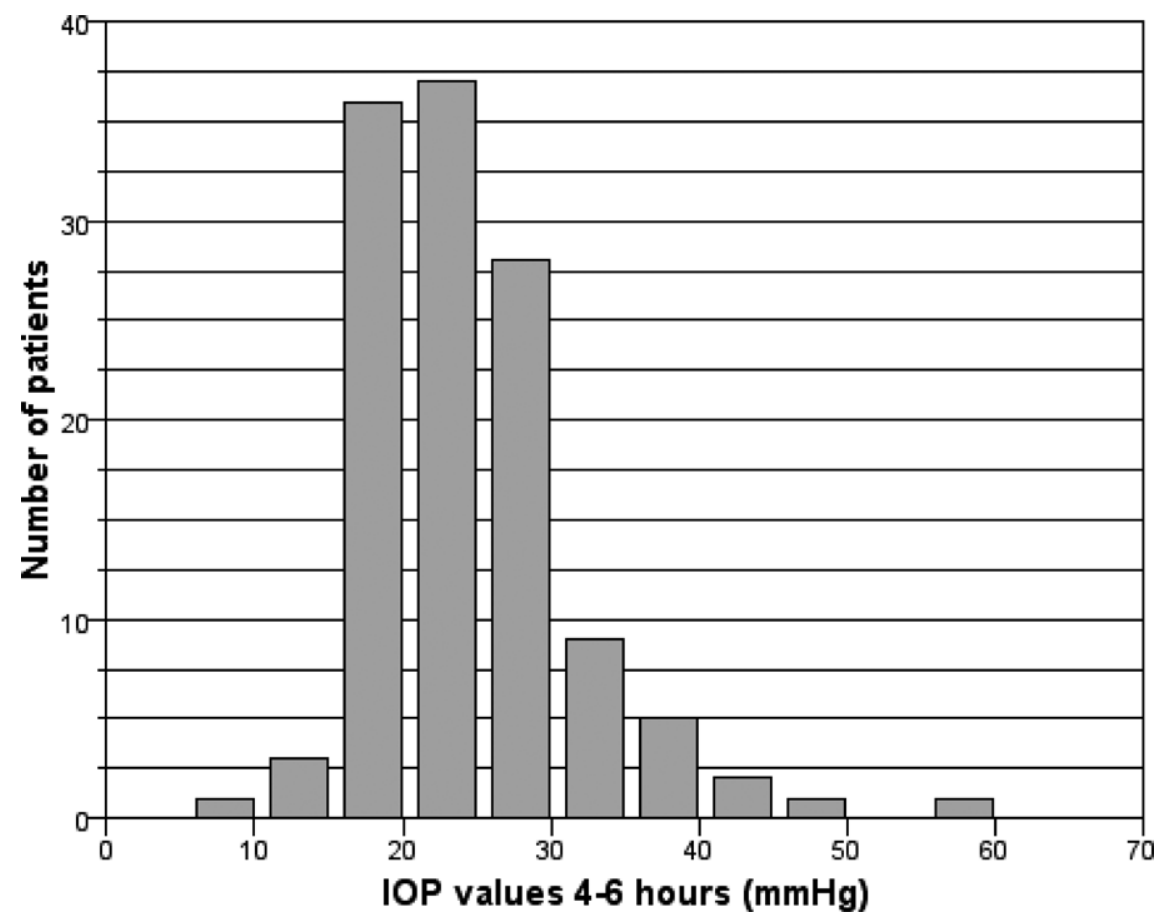

Fig. 2. Values of intraocular pressure (IOP) 4-6 hours after phacoemulsification.

( $\mathrm{p}<0.05$ ), six patients had IOP over $22 \mathrm{~mm} \mathrm{Hg}$, and the highest measured IOP was $24 \mathrm{~mm} \mathrm{Hg}$ in only one patient (Fig. 4). However, there still was a statistically significant difference $(\mathrm{p}<0.05)$ between the IOP measured preoperatively and the IOP measured seven days after the surgery (Table 1). 




Fig. 3. Values of intraocular pressure (IOP) 18-24 hours after phacoemulsification.



Fig. 4. Values of intraocular pressure (IOP) 7 days after phacoemulsification.

\section{Discussion}

Transient increases in IOP occur in the immediate period after cataract surgery, as shown in our research, which is consistent with previous researches ${ }^{4,5}$. It is difficult to predict preoperatively which patients are prone to the rise of IOP. Immediately after cataract 
Table 1. Mean changes in intraocular pressure (IOP)

\begin{tabular}{|l|l|l|l|l|}
\hline Change in IOP over time $(\mathrm{mm} \mathrm{Hg})$ \\
\hline Preoperatively & & $4-6$ hours & $18-24$ hours & 7 days \\
\hline Mean & $15.10 \pm 2.68(\mathrm{SD})$ & $24.29 \pm 7.56(\mathrm{SD})$ & $18.37 \pm 4.80(\mathrm{SD})$ & $16.24 \pm 2.90(\mathrm{SD})$ \\
\hline Range & $9-22$ & $8-60$ & $6-40$ & $8-24$ \\
\hline
\end{tabular}

surgery, IOP elevation occurs as early as two to three hours after surgery and usually normalizes within a week $^{6,7}$. IOP rise can be caused by various mechanisms. Coban et al. ${ }^{8}$ found the diagnosis of glaucoma to be the only risk factor. Furthermore, it was concluded that pseudoexfoliation was not a risk factor for high IOP. On the other hand, Pohjalainen et al. ${ }^{9}$ conclude that early IOP should be monitored carefully, especially in the eyes with exfoliation.

Several studies confirmed the impact of viscosurgical devices on early postoperative IOP rise ${ }^{10,11}$. Biro et $a l^{7}$ confirmed that retention of viscosurgical devices behind the IOL resulted in a significantly increased postoperative IOP at all measured intervals. It is, therefore, important to remove as much of ocular viscoelastic device (OVD) as possible at the end of surgery. Additionally, Chaudhary and Kadyan ${ }^{12}$ and Kim et al. ${ }^{13}$ confirmed the experience of surgeons to have an important impact on IOP elevation. These findings were not surprising since beginners often perform intraocular surgery in a more traumatizing manner than experienced surgeons do. A stronger trauma leads to a more pronounced release of serum proteins and iris pigment into the anterior chamber and to a greater direct damage to the trabecular meshwork ${ }^{14}$. In our research, the same highly experienced surgeon operated all patients. She used the same technique and the same OVD in all patients. Thereby, we excluded surgical experience as a factor for transient IOP rise. IOP is not measured routinely at the end of cataract surgery. The surgeon usually leaves the eye adequately filled, so the anterior chamber is formed and the IOP feels 'right', which is determined by digital pressure. This is a rough estimate and accuracy can vary greatly among different eyes, even for the same surgeon ${ }^{15}$. As noted above, some patient categories were excluded from the study, i.e. optic nerve/disc changes suggestive of glaucomatous damage, patients with previous eye trauma, pseudoexfoliation syndrome, glaucoma, prior intraocular surgery and those developing any complication during or after surgery. In spite of these exclusions, at 4-6 hours after the surgery, IOP values were above $22 \mathrm{~mm}$ $\mathrm{Hg}$ in 75 (60.9\%) patients, above $30 \mathrm{~mm} \mathrm{Hg}$ in 25 (19.4\%) patients and above $40 \mathrm{~mm} \mathrm{Hg}$ in six patients. One patient had IOP value of even $60 \mathrm{~mm} \mathrm{Hg}$. Unlike the results reported by Cheon et al. ${ }^{3}$, where none of the patients had IOP values of more than $30 \mathrm{~mm} \mathrm{Hg}$ one day postoperatively, we had two patients with IOP value above $30 \mathrm{~mm} \mathrm{Hg}$, one of them even $40 \mathrm{~mm} \mathrm{Hg}$. Although there were leaps in IOP, none of the patients developed any serious visual complication. Nonetheless, our study had some limitations. We used two different IOL types (LEDAphil Hydrophilic IOL and LEDAphob Hydrophobic IOL, Hempro Ltd., Solihull Birmingham, United Kingdom), which was not taken into consideration during the postoperative measurement of IOP. Furthermore, we did not measure the early postoperative central corneal thickness, which could affect the measured IOP values.

Attention is paid mostly to the follow up of patients with glaucoma due to possible IOP rise postoperatively. Our research revealed that even eyes with normal preoperative values and uncomplicated phacoemulsification course could show very high IOP values postoperatively, which can cause pain, blurred vision and, rarely, compromise visual function. Although patients without optic nerve damage seem to tolerate transient increases in IOP without problems ${ }^{16}$, we must be aware of and understand the various treatment options for elevated IOP. It is difficult to predict postoperatively which patients are in a high-risk group. It is necessary to observe carefully IOP leaps and their influence on postoperative visual acuity.

\section{References}

1. Zetterstorm C, Eriksson A. Changes in intraocular pressure following phacoemulsification and implantation of a posterior chamber lens. Eur J Implant Ref Surg. 1994 Feb;6:809-13. doi: 10.1136/bjo.79.9.809

2. McCulley TJ. Ischemic optic neuropathy and cataract extraction: what do I need to know? Oman J Ophthalmol. [serial 
online] 2012. [cited 2016 Jun 28];5:141-3. doi: 10.4103/0974620X.106090

3. Cheon M, Kim Y, Lee J, Kim J, Kook M, Tchah H. Homeostatic response of intraocular pressure in the early period after sutureless phacoemulsification. J Cataract Refract Surg. 2012; 38:124-8. doi: 10.1016/j.jcrs.2011.07.039.

4. Zamani M, Feahhi M, Azarkish A. Early changes in intraocular pressure following phacoemulsification. J Ophthalmic Vis Res. 2013 Jan;8(1):25-31.

5. Byrd S, Singh K. Medical control of intraocular pressure after cataract surgery. J Cataract Refract Surg. 1998 Nov;24: 1493-7. doi: 10.1016/s0886-3350(98)80172-7

6. Kim JW, Korean J. Comparative study of intraocular pressure change after cataract surgery: phacomeulsification and extracapsular cataract extraction. Ophthalmology. 1996;10:104-8. doi: 10.3341/kjo.1996.10.2.104

7. Biro Z, Balogh T. Change in intraocular pressure within 1 week of phacoemulsification and intraocular lens implantation using Adatocel.J Cataract Refract Surg. 2006;32:573-6. doi: 10.1016 /j.jcrs.2005.12.105

8. Coban-Karatas M, Sizmaz S, Altan-Yaycioglu R, Canan H, Akova YA. Risk factors for intraocular pressure rise following phacoemulsification. Indian J Ophthalmol. 2013;61:115-8. doi: 10.4103/0301-4738.99997

9. Pohjalainen T, Vesti E, Uusitalo RJ, Laatikainen L. Phacoemulsification and intraocular lens implantation in eyes with open angle glaucoma. Acta Ophthalmol Scand. 2001;79:313-6.
10. Vajpayee R, Verma K, Sinha R, Titiyal J, Pandey R, Sharma N. Comparative evaluation of efficacy and safety of ophthalmic viscosurgical devices in phacoemulsification. BMC Ophthalmology. 2005;5:17.

doi: 10.1186/1471-2415-5-17

11. Olivius E, Thorburn W. Intraocular pressure after cataract surgery with Healon. Intraocular Implant Soc J. 1985 Sep;11: 480-2.

12. Chaudhary R, Kadyan A. First postoperative day intraocular pressure rise in resident-performed cataract surgery. Eye. 2012;26(7):1026.

doi: 10.1038/eye.2012.70

13. Kim JY, Jo M-W, Brauner SC, et al. Increased intraocular pressure on the first postoperative day following resident-performed cataract surgery. Eye. 2011;25(7):929-36. doi: 10.1038/ eye. 2011.93

14. Bömer TG, Lagrèze WD, Funk J. Intraocular pressure rise after phacoemulsification with posterior chamber lens implantation: effect of prophylactic medication, wound closure, and surgeon's experience. Br J Ophthalmol. 1995;79(9):809-18. doi: 10.1136/ bjo.79.9.809

15. Antao S, Kasaby H. Evaluation of intraocular pressure at the end of cataract surgery. J Cataract Refract Surg. 2008 Feb; 34(2):258-61. doi: 10.1016/j.jcrs.2007.08.045

16. Johnson S. Cataract Surgery in the Glaucoma Patient: Elevated Intraocular Pressure after Cataract Surgery. Springer Science and Business Media. 2009:51-5. ISBN 978-0-387-09408-3

Sažetak

\section{PROMJENE INTRAOKULARNOG TLAKA NAKON NEKOMPLICIRANE FAKOEMULZIFIKACIJE U RANOM POSLIJEOPERACIJSKOM RAZDOBLJU U ZDRAVIM OČIMA}

\section{Todorović, T. Šarenac Vulović, N. Petrović, D. Todorović i S. Srećković}

Cilj rada je bio utvrditi rane promjene intraokularnog tlaka (IOT) nakon fakoemulzifikacije i implantacije intraokularne leće (IOL) u zdrave oči. Ova prospektivna interventna studija slučaja provedena je na Oftalmološkom odjelu Kliničkog centra Kragujevac u Kragujevcu, Srbija. Studija je obuhvatila 123 oka bolesnika s kataraktom, 66 žena i 57 muškaraca, u dobi od 50-88 (srednja dob 70,73 $\pm 7,94$ ) godina, koji su bili podvrgnuti fakoemulzifikaciji i implantaciji IOL u kapsularnu vrećicu. Bolesnici su liječeni u Kliničkom centru Kragujevac između lipnja 2015. i svibnja 2016. godine. IOT je mjeren Goldmannovim aplanacijskim tonometrom prijeoperacijski, a zatim 4-6 sati, 18-24 sata i 7 dana poslijeperacijski, a mjerenja je obavio isti ispitivač. Srednja vrijednost IOT prijeoperacijski je iznosila 15,10 $\pm 2,68 \mathrm{~mm} \mathrm{Hg}$. Kod tri bolesnika najviši izmjereni IOT bio je $22 \mathrm{~mm} \mathrm{Hg}$. Kod mjerenja provedenog 4-6 sati poslijeoperacijski srednja vrijednost IOT bila je 24,29 $\pm 7,56 \mathrm{~mm} \mathrm{Hg}$ ( $\mathrm{p}<0,001)$, zatim u $18-24$ sata bila je $18,37 \pm 4,80 \mathrm{~mm} \mathrm{Hg}(\mathrm{p}<0,001)$, a 7 dana nakon operacije srednja vrijednost IOT bila je $16,24 \pm 2,90 \mathrm{~mm} \mathrm{Hg}(\mathrm{p}<0,05)$. Izmjerene vrijednosti IOTbile su statistički značajne u svim vremenima mjerenja. Međutim, u 4-6 sati i 18-24 sata srednja vrijednost IOT bila je visoko statistički značajna ( $<<0,001)$. Iako se 7 dana nakon operacije vrijednost IOT normalizirala, srednja vrijednost je bila statistički značajna $(p<0,05)$. U zaključku, naše istraživanje je pokazalo da čak i oči s normalnim prijeoperacijskim vrijednostima i nekompliciranim tijekom fakoemulzifikacije mogu pokazivati vrlo visoke vrijednosti IOT, što može uzrokovati bol, zamagljen vid i, rijetko, ugroziti vidnu oštrinu.

Ključne riječi: Intraokularni tlak; Fakoemulzifikacija; Léé, intraokularne, ugradnja; Tonometrija, okularna 